\title{
Boys, Boyhood and the Construction of Masculinity
}

\author{
Guest Editor's Introduction \\ Heather Ellis \\ Balliol College, Oxford
}

\begin{abstract}
This introductory article explains the aims of the interdisciplinary conference "Masculinity and the Other" held at Balliol College, Oxford, August 29-30, 2007, at which all of the papers comprising this special issue of Thymos: Journal of Boyhood Studies were first presented. It points out the prominence which the notions of the "boy" and boyhood and the life-cycle enjoyed at the conference and seeks more generally to suggest the benefits a more fully integrated discussion of these topics might bring to the fields of masculinity and gender studies.
\end{abstract}

Keywords: boys, boyhood, masculinity

In the scholarship of the last twenty years, there has been a major move away from treating gender as an essentialist identity. In particular, men's studies, which developed in the 1980s in response to a predominantly feminist critique of male power structures, have undergone a veritable sea-change. Instead of stressing the idea of innate and fundamental differences between men and women (sometimes termed the "separate-anddifferent cultures" model ${ }^{1}$ ), masculine identity has been increasingly treated as a highly contingent social construct. No longer is the study of masculinity restricted to a relatively small number of academic fields (primarily sociology, psychology and cultural studies), but has become instead one of the most vibrant areas of interdisciplinary investigation. R.W. Connell (1998) has referred to this change as the "ethnographic moment" of the 1990s, when history, cultural anthropology and other disciplines grounded in empirical research and focused on the importance of cultural context became increasingly interested in the formation of male identity. The emergence of a range of

${ }^{1}$ For a useful explanation of this model, see Thorne (1993, pp. 89-110). See, for example, Haywood and Mac an Ghaill (2003).

Heather Ellis, Balliol College, Oxford.

Correspondence concerning this article should be addressed to Heather Ellis, Balliol College, Oxford OX13BJ, United Kingdom. Electronic mail: heather.ellis@balliol.ox.ac.uk

THYMOS: Journal of Boyhood Studies, Vol. 2, No. 2, Fall 2008, 119-124.

(C) 2008 by the Men's Studies Press, LLC. All rights reserved. http://www.mensstudies.com thy. $0202.119 / \$ 12.00$

DOI: $10.3149 /$ thy.0202.119

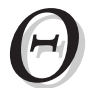


new sub-disciplines focused on the study of masculinity has been the result. Prominent among these has been the history of masculinity which developed under the auspices of scholars such as John Tosh and Michael Roper in the early 1990s (Tosh \& Roper, 1991; Tosh, 1994), and has since become one of the most popular and innovative fields of historical inquiry.

The move towards interdisciplinarity in masculinity studies has been accompanied by growing scepticism about the predominantly structuralist analyses which informed men's studies in the late 1970s and 1980s. Increasingly, scholars have questioned the claim of writers such as Andrew Tolson (1977) and Jeff Hearn (1987) that socio-economic structures and power relations have been chiefly responsible for determining forms of masculinity. In the 1990s, R.W. Connell (1995), among others, argued for a multiplicity of masculinities which did much to undermine existing ideas of male identity as essential and universal, possessed by all men, regardless of age, class, ethnicity or any other cultural marker. In recent years, however, Connell's own work has been criticized for being too closely wedded to a neo-Marxist methodology which unduly privileges the role played by power relations in the formation of identity. With the increasing popularity of social constructionist theories in masculinity studies, scholars such as Chris Haywood and Mairtin Mac an Ghaill (1997) have questioned Connell's emphasis on hegemony and hierarchy, arguing that it underestimates the extent to which the formation of masculine identity is characterized by fluidity, fragmentation and contradiction. Clearly, the impact of power relations cannot be ignored in any study of masculinity; their role, however, must be problematized as part of a critical analysis which does not treat them as constant and immovable.

In addition, some have argued that Connell's pro-feminist stance and preoccupation with the concept of gender oppression has led her to overestimate the importance of the male-female binary in the construction of masculine identity. More recently, scholars have stressed the need to examine how a variety of cultural markers such as age, class and ethnicity, as well as gender, interact and combine in the complex process of identity formation. It was with this aim in mind that we organized the conference at Balliol College, Oxford, August 29-30, 2007, where all of the essays in this special issue were first presented. By calling the conference "Masculinity and the Other" we sought to focus attention on the process of construction itself. In particular, following calls from scholars such as Stefan Collini (1991) and John Tosh (1994), we wanted to investigate the role and importance of non-female "others." 2 The majority of papers, therefore, explored a range of male "others" including immature males, working-class males, and exotic males. A number of papers chose to interrogate the familiar terms "man" and "manliness." While some considered "man" in its most familiar gendered sense, others focused on its alternative, yet related meanings of "adult" and "human." In some contexts, then, such as in all-male educational institutions, "manliness" was found frequently to have connoted the possession of age and maturity in preference to

${ }^{2}$ For more information on the aims of the conference and a further selection of conference papers, see Ellis \& Meyer (forthcoming, 2009). For examples of this approach, see Cameron and Bernardes (1998) and Rogers (2008). 
the gendered characteristics of masculinity; in others, it seems to have been primarily intended to distinguish "humane" virtues from the inhuman and the bestial.

As well as exploring the diversity of "others" employed in the construction of masculine identities, we were keen to encourage papers which focused on male groups traditionally neglected in scholarship. It was felt that the strong emphasis placed on concepts of hierarchy and hegemony in much recent work on masculinity had led to an over-privileging of male subjects in positions of power and authority. For many groups, such as boys and adolescents, working-class men and homosexual men, a recognition of agency in the process of identity formation has often been lacking. In recent years, increasing importance has been laid on recovering and reconstructing so-called "subaltern" and "marginalized" masculinities; however, here too, we can see the continued preoccupation with the impact of power relations to the exclusion of other factors affecting identity formation. Among the papers we selected were a number interested in exploring marginalized groups as active subjects, capable of fashioning their own masculine identities and not necessarily concerned primarily with their own inferior position. Particularly prominent here were papers included in the panels dealing with themes of "youth and age" and "fatherhood." Indeed, the role of boys and adolescent males in fashioning their own identities was considered in several papers including some of those making up this special issue of Thymos.

The decision to include papers which took seriously boys' agency in the process of identity formation was based on the belief that boys should not be considered solely as objects in the construction of adult masculine identity. In the first issue of Thymos, the editors expressed a similar conviction (Groth \& Janssen, 2007). In stating their commitment to "saving the phenomenon" of the boy, they made clear that an integral part of this project was a belief in the individual and collective agency of boys in developing identities of their own (p. 3). Equally important, they stressed, was the need to open up gender studies (the field in which boys and boyhood have traditionally been examined) to insights gained from other disciplines. The study of boys and boyhood has much to recommend it to scholars of masculinity. Most obviously, it provides an excellent opportunity to explore the ways in which distinctions of gender interact and combine with those of age, a cultural marker whose importance has been the subject of increasing scholarly attention in recent years.

Perhaps more than any other aspect of identity, age allows us to access the fragmented, shifting, ever-changing nature of masculine identity which scholars have been emphasizing in recent work. For age is by its very nature liminal and transitional and boyhood has a good claim to be considered the liminal experience par excellence. In the words of John Burnside (1996), it is the period when human beings are most "susceptible to change: where being is raw, as it were, where identity is less fixed, more open to possibility" (p. 203). Some eight years ago, Anne Scott Sørensen (2000) commented on the particular ability of "boy-centered research" to "open the field of gender studies to multiplicity and diversity [...] and thus keep [it] at the center of academic severity" (p. 240).

However, we have to be aware of the possibility that in shifting the focus of research in masculinity studies to the interaction of gender with other cultural markers, we may actually undermine the integrity of the discipline itself, for an examination of the roles played by other factors such as age, class and race in the construction of identity can only lead to the qualification of the importance of gender itself. Yet if we are 
committed, first and foremost, to a study of identity, then we must be open to the idea that a better understanding of it may only be achieved when gender is seen as but one among several competing sets of distinctions which inform and shape people's sense of self. There is no need, though, to see this as resulting necessarily in the reduction of the many different facets of human identity to one level. The challenge is to discover the peculiar conditions (the when, where, and why) under which gender does take centre stage in the process of identity formation. Postmodern theorists of subjectivity such as Stuart Hall have been stressing the need for some time now to move away from a narrow focus on particular facets of identity and to consider the entirety of individual subjectivity as the object of enquiry. Unless masculinity studies (and, more broadly, gender studies) take this conclusion onboard, the future viability of the disciplines may be in doubt, for as Hall (2000) has warned, "identities [...] are never unified and, in late modern times, [are] increasingly fragmented and fractured; never singular but multiply constructed across different, often intersecting and antagonistic, discourses, practices and positions" (p. 17).

Collaborative interdisciplinary projects like Thymos and the conference on "Masculinity and the Other" may well be one way forward. Although the primary focus of the papers selected for this issue is masculine identity formation during boyhood, they are also concerned with exploring the ways in which distinctions of gender shape and are shaped by other aspects of subjectivity — primarily age — but also, class, "race", citizenship and nationality. Complementing Thymos' emphasis on interdisciplinarity, the contributors hail from a variety of scholarly disciplines (cultural history, psychology, classical studies, and comparative literature) and employ a distinctly interdisciplinary approach, frequently ranging outside the confines of their own discipline. Likewise, the essays are broad in terms both of their chronological and geographical range. While Henrik Berg focuses his attention on the construction of masculinities in Hellenistic Greece ( $3^{\text {rd }}$ Century BC), Anne Markey examines the importance of "boyish spirituality" in the works of Patrick Pearse in early twentieth-century Ireland. Pauline Farley, by contrast, investigates constructions of ideal masculinity for boys in English children's annuals throughout the twentieth century, while Alexander Clarkson examines the presentation of heroic masculinities in boys' war comics in Cold-War America, Britain and Germany. Finally, with Damien Riggs' paper we are brought up to the present day with an exploration of the treatment of fatherhood in early twenty-first century books on raising boys.

Common to all the papers is a focus on literature as a source for the study of masculinity and boyhood. While some essays (Markey, Clarkson and Farley) are concerned with literature designed primarily for boys by adult male writers, others (Berg and Riggs) focus on texts which represent and describe boys and their behavior. Taken together, the essays testify to the great variety of ways in which literature, viewed as a form of intergenerational communication, can shape the relationships between boys and adult men. While Markey, Farley and Clarkson focus on literature written primarily for an adolescent male readership, they highlight the very different ways in which that literature was used. On the one hand, Farley shows how boys' annuals in twentieth-century England recreated to a surprising degree codes of moral and physical masculinity inherited from the Victorian era; Markey and Clarkson, on the other hand, stress the creative ways in which particular ideals of boyhood were employed to strategically critique dominant ideals of adult masculinity. Thus, Markey shows how Patrick Pearse 
employed shifting constructs of Irish boyhood to oppose the form of imperial masculinity he saw as embodying Britain's political and cultural oppression of his country. Clarkson, meanwhile, reveals how images of "good" and "bad" boys were used strategically in war comics to criticize the civilian population of America for not sufficiently supporting the Vietnam War. Nor are boys themselves presented as being without agency in these constructions. In all three papers, emphasis is placed on real boys' interactions with literature as well as the writers' own familiarity with the world of boys.

The active construction of boyhood and male adolescence is an equally prominent feature of the literature focused on by Riggs and Berg. Although not directed at boys themselves, both the books examined by Riggs and the Menandrian comedies explored by Berg directly engage with the everyday lives and self-perceptions of the boys they describe. We know that boys, when approaching manhood, would accompany their fathers to see comedies performed in Hellenistic Greece; similarly, Riggs' parenting books were designed to shape the interactions of real fathers with their sons. Just as with the literature aimed directly at boys, we can see concepts of "boys" and "boyhood" being used creatively by the respective writers. Riggs demonstrates the ways in which contemporary parenting books, although not overtly homophobic, nonetheless succeed in creating an artifical, yet powerfully persuasive construct of the "average boy." Berg, by contrast, shows how Menander used his adolescent male characters as part of a broader strategy to represent ideal forms of masculinity in his plays.

A final feature of the selected papers (and one particularly significant for the mission of Thymos) is their willingness to call into question the very meaning of the terms "boy" and "boyhood." Thus Clarkson's essay examines the effect of depicting adult men as overgrown boys in comics, which although designed for an adolescent readership were, in fact, also read by many middle-aged men nostalgic for the stories of their boyhood. Berg, meanwhile, considers the phenomenon of an "extended" boyhood in Hellenistic Greece and asks whether physical or mental age (maturity) was more important in defining the limits of boyhood in this society. In different ways, both Markey and Farley discuss the profound symbolic power of "the boy" in situations frequently disconnected from the lives of real boys, while Riggs demonstrates how in contemporary parenting books the cultural status of "boy" has been consistently denied to boys who identify as gay or otherwise demonstrate "abnormal" sexual proclivities.

Altogether, we think that this special issue brings together a range of papers which offer fresh perspectives on the interrelation of gender and age in the process of identity formation. This has recently become a question of central importance, not only to the study of masculinity but also to the emerging field of life-course studies. The contributors have chosen to focus attention on the enigmatic figure of the boy. Their investigations reveal his considerable significance as a site for exploring the complex connections between distinctions of age and distinctions of gender, both in the past and in contemporary society. While some contributors consider the boy primarily as the object upon which other males inscribe their notions of masculinity, others highlight his importance as an active subject, engaged in the construction of his own masculine identity. All, however, demonstrate the value of focusing attention on this liminal and transitional figure when investigating how different facets of identity interact and combine. In so doing, they fulfil one of the most important aims of the conference where their ideas were first presented. 


\section{References}

Burnside, J. (1996). Poetry and a sense of place. Nordlit. Arbeidstidsskrift i litteratur, 1, 201-222.

Cameron, C., \& Bernades, D. (1998). Gender and disadvantage in health: Men's health for a change. Sociology of Health and Illness, 20(5), 673-693.

Collini, S. (1991). Public moralists: Political thought and intellectual life in Britain 1850-1930. Oxford: Clarendon Press.

Connell, R.W. (1995). Masculinities. Cambridge: Polity.

Connell, R.W. (1998). Masculinities and globalization. Men and Masculinities, 1(1), 3-23.

Ellis, H., \& Meyer, J. (Eds.). (forthcoming, 2009). Masculinity and the other: Historical perspectives. Newcastle: Cambridge Scholars Publishing.

Groth, M., \& Janssen, D.F. (2007). Editors' welcome. Thymos: Journal of Boyhood Studies, 1(1), 3-5.

Hall, S. (2000). Who needs 'identity'? In P. du Gay, J. Evans, \& P. Redman (Eds.), Identity: A reader (pp. 15-30). London: Sage.

Haywood, C., \& Mac an Ghaill, M. (1997). Materialism and deconstructivism: Education and the epistemology of education. Cambridge Journal of Education, 27(2), 261-272.

Haywood, C., \& Mac an Ghaill, M. (2003). Men and masculinities: Theory, research and social practice. Buckingham, Philadelphia: Open University Press.

Hearn, J. (1987). The gender of oppression: Men, masculinity and the critique of Marxism. New York: St. Martin's Press.

Rogers, M. (2008). Modernity, 'authenticity', and ambivalence: Subaltern masculinities on a South Indian college campus. Journal of the Royal Anthropological Institute, 14(1), 79-95.

Sørensen, A.S. (2000). Becomings: Studies in boys, men and masculinity. Young, 8(4), 40-51.

Thorne, B. (1993). Gender play: Girls and boys in school. New Brunswick, NJ: Rutgers University Press.

Tolson, A. (1977). The limits of masculinity. London: Tavistock.

Tosh, J. (1994). What should historians do with masculinity? Reflections on nineteenth-century Britain. History Workshop Journal, 38(1), 179-202.

Tosh, J., \& Roper, M. (1991). Manful assertions: Masculinities in Britain since 1800. New York: Routledge. 